\title{
Human Resources Transformation in the Digitalization Professional Era in North Sumatera
}

\author{
Lailan Tawila Berampu ${ }^{1 *}$, Windy Dian Sari ${ }^{2}$ \\ ${ }^{1}$ Universitas Medan Area, ${ }^{2}$ STAI Fatahillah Serpong \\ 1lailan_tawila@yahoo.com, ²windyahmad2000@gmail.com \\ *Corresponding author
}

\begin{abstract}
The readiness of the Province of Sumatera Utara in the era of digitalization in the face of free-market competition inevitably starts from the transformation of human resources (HR). Digital HR transformation is very important in an era where technological disruption is the usual norm where revolutionary changes occur but also the phenomenon of evolution in organizations. In addition to digitalization, the transition to business with technology at the centre also requires changes in technology, education, skills and organizational innovation. This cannot be denied, including the government in increasing human resources is one way that can be done to be able to compete in the international world. This study is intended to obtain data and information about the transformation of HR in Sumatera Utara to increase competitiveness in the digital era. The transformation of HR in Sumatera Utara in the digital era was shaped by the dimensions of technology and innovation.
\end{abstract}

Keywords: Human Resources, Digital Era

\begin{abstract}
Abstrak
Kesiapan Provinsi Sumatera Utara di era digitalisasi dalam menghadapi persaingan pasar bebas niscaya berawal dari transformasi sumber daya manusia (SDM). Transformasi SDM digital sangat penting di era di mana disrupsi teknologi adalah norma yang biasa terjadi di mana perubahan revolusioner terjadi tetapi juga fenomena evolusi dalam organisasi. Selain digitalisasi, transisi ke bisnis dengan pusat teknologi juga membutuhkan perubahan dalam teknologi, pendidikan, keterampilan, dan inovasi organisasi. Hal tersebut tidak dapat dipungkiri, termasuk pemerintah dalam meningkatkan sumber daya manusia merupakan salah satu cara yang dapat dilakukan untuk dapat bersaing di dunia internasional. Penelitian ini bertujuan untuk memperoleh data dan informasi tentang transformasi SDM di Sumatera Utara dalam rangka meningkatkan daya saing di era digital. Transformasi SDM Sumatera Utara di era digital dibentuk oleh dimensi teknologi dan inovasi.
\end{abstract}

Kata kunci: Sumber Daya Manusia, Era Digital

Cara Mengutip:

Berampu, L.T., Sari, W. D. (2020). Human Resources Transformation in the Digitalization Professional Era in North Sumatera. Esensi: Jurnal Bisnis dan Manajemen. Vol. 10 (2): 135-146. DOI: https://doi.org/10.15408/ ess.v10i2.18477 


\section{INTRODUCTION}

In the digital era and the current era of globalization, the provincial government is required to take appropriate, fast, accurate and bold steps and policies to make breakthroughs and creative innovations that are oriented towards the interests of the wider community. This demand is essential in the framework of increasing regional competitiveness to create a competitive advantage, all of which are for the sake of improving the welfare of the community. One of them is Human Resources development. Human Resource Development should focus on developing individual capacities to respond to the entire context of institutional responsibilities and duties (Fenech, Baguant, \& Ivanov, 2019).

The industrial revolution 4.0 that we feel has presented various new technological devices in the form of electronic devices that have changed the fast activities of human life in various fields of life at large (Ustundag \& Cevikcan, 2018). To face the current 4.0 industrial revolution, it is necessary to endeavour to make innovations in the field of human capital. In facing this challenge, Human Resources (HR) is an important keyword in realizing development in facing the era of disruption. For this reason, it is necessary to transform digital-based HR. Digital transformation studies are continuously being carried out within organizations to adapt to this new digital business ecosystem. Apart from technological adaptation, structural changes in processes, human resources, and corporate culture also occur in the digital transformation process (Türkmen, 2020).

Since Indonesia decided to open up and establish bilateral relations with other countries, many changes have had an impact, especially in the regional economic sector. The forms of cooperation that are established are very diverse, ranging from economic cooperation, education, tourism, and employment as well as other fields. The 21st century is marked by this era of digitalisation and globalization. the readiness of the government in facing various challenges as well as opportunities in facing the Industrial Revolution 4.0. HR strategies need to be carefully prepared to be able to produce competitive outputs at the regional and world levels (Guler, Guillén, \& Macpher, 2002).

On the other hand, the quality of human resources is a determining factor for the success of the development and progress of a nation. The experiences of ASEAN countries such as Thailand, Singapore and Malaysia prove the truth of this, where the two countries have succeeded in making ASEAN economic revival through their success in driving the economic progress of their countries spectacularly and amazingly. Their progress is not based on abundant natural wealth, but the quality of their human resources. However, for Indonesia, the problem of human resources is still the main problem. We realize that the quality of Indonesia's human resources is much lower than that of other countries at a similar stage of development to us and even in the ASEAN region.

Indonesia can be said to have succeeded in becoming a country with a fairly high Human Development Index (HDI) in Asia according to the 2019 HDI report from the United Nations Development Program (UNDP). Indonesia's Human Development Index (HDI) or the Human Development Index (HDI) of 0.707. Meanwhile, other Asian countries such as the Philippines have an HDI of 0.712 and China with an HDI of 0.758. Indonesia is already a country with a high human development index. This is the first time since the HDI was launched in 1990. Indonesia has achieved significant improvements, but gaps remain an 
unresolved problem. UNDP divides the index into low, medium, high and very high categories. The range for the tall category is from 0.700 to 0.799 . Recent reports show that there are 62 countries in the very high category, including Singapore in ninth place, Brunei Darussalam at 43 and Malaysia at 61. Indonesia is among the 54 countries in the high category, along with Thailand in 77th place and the Philippines in 106th (United Nations Development Programme, UNDP, 2019).

Sumatera Utara Province also continues to strive to improve the quality of human resources as reflected in the Human Development Index. Judging from the HDI of Provinces in Indonesia, Sumatera Utara Province was number 8 in 2009. The human development index (HDI) of Sumatera Utara province in 2017 was recorded at 70.57\%, an increase of 0.57 points or $0.81 \%$ compared to the previous year (https://ipm.bps.go.id/ data/provinsi/ metode/baru/1200, accessed on May 11 2020).

Sumatera Utara Province must also be ready to face each of these challenges, where every citizen must produce better performance because the abilities that have been obtained through education and training greatly affect the quality of human resources itself. Because in today's social life, Science and Technology plays an important role and continues to develop and experience many changes in various areas of life in intellectual capital, organizational learning, and investment in information technology in increasing the competitive advantage of a company (Salim, Harta, Shania, \& Devie, 2019). To be able to compete with ASEAN countries, Indonesia in general and Sumatera Utara Province in particular must increase research and development that leads to innovation. This is certainly a challenge and an opportunity for the Province of Sumatera Utara. It has considerable natural and human resource potential so that it can compete by improving the quality of its human resources.

The readiness needed is the competence itself consisting of knowledge, skills, and attitudes. These three factors have an equally important role in being able to produce output in the form of maximum performance, thus encouraging the achievement of company objectivity. The world of education in general equips us in terms of knowledge and skills, and generally focuses more on hard technical skills and human resource development needs to be improved the capacity and skills of workers (Tîţu, Stanciu, \& Țîtu, 2018). Transformation of human resources is one of the key factors in economic reform, namely how to create qualified and skilled human resources who are highly competitive in global competition which we have always neglected.

Human resource or employment problems if not managed properly from the start will result in unwanted social problems later in the day. The cause of HR problems is not only a technical problem, but also concerns economic, social, organizational and educational issues ((Kamukama, 2013). HR capital is always associated with the knowledge and skills that exist in human resources. Human resources influence economic growth in several ways, namely: human capital which is one of the input factors in the production function and the accumulation of human capital will encourage positive externalities in the economy which in turn lead to endogenous growth. Accumulation of human capital also leads to innovation. Innovation in the economy that arises from the quality of human resources is increasingly important (Higgins, 2014). In terms of physical capital investment, the accumulation of 
human capital also pushes the level of investment to a higher level which causes the socalled 'second order effect on growth performance (Mankiw, 2006)

\section{METHODS}

This research was conducted in Sumatera Utara Province. The data comes from two main sources, namely primary data. Primary data comes from a list of questions (questionnaire) directed to company leaders consisting of industry, hospitals, plantations, finance, and tourism regarding the readiness of their human resources in facing the digitalization era. The selection of this population is because they directly have the capability and ability to be able to compete with similar industries in other countries. The population number of each object, are:
1. Big Industries : 107
2. Hospitals : 15
3. Plantations : 25
4. Banks : $: 36$
5. Hotels : 10

Thus the number of samples taken in this study with a proportionate stratified random sampling method. Stratified random sampling is a sampling method by first classifying the population into strata based on certain criteria then simply selecting each stratum. Meanwhile, to determine the number of samples (n) 30\% quoted by Husein Umar (2004: 78), to determine the sample the following formula is used: Thus the number of samples taken is equal to:

$\begin{array}{lll}\text { 1. } & \text { Big Industries } & : 33 \\ \text { 2. Hospitals } & : 6 \\ \text { 3. Plantations } & : 8 \\ \text { 4. Banks } & : 12 \\ \text { 5. Hotels } & : 2\end{array}$

From each sample company, a minimum of 3 respondents will be taken from the level of manager level and above to directors related to the transformation of professional millennial human resources in the era of digitalization.

\section{RESULT AND DISCUSSION}

The number of respondents used in this study was 203 people. This number has been considered to meet the criteria, because the minimum sample size is for research using Structural Equation Modeling (SEM) statistical tools with the Maximum Likelihood Estimation (MLE) procedure. After the fit of the model and the data as a whole is good, the next step is to evaluate or test the fit of the measurement model. This evaluation is carried out on each construct or measurement model (the relationship between a latent variable and several observed variables separately through evaluation of the validity of the measurement model and evaluation of the reliability of the measurement model. 
To measure reliability in SEM, the composite reliability measure and variable extracted measure are used.

Table 1. Construct Reliability Model Stability Alienation

\begin{tabular}{lcc}
\hline \multicolumn{1}{c}{ Latent Variable } & Construct Reliability & Conclusion \\
\hline Technology & 0.91 & Good \\
Education & 0.86 & Good \\
Skill & 0.89 & Good \\
Innovation & 0.80 & Good \\
Human Resources & 0.77 & Good \\
\hline
\end{tabular}

The results of the reliability calculation above can be summarized in the table and it can be seen that all values of Construct Reliability (CR) $\geq 0.70$. Thus it can be concluded that the reliability of the measurement model (construct) is good.

Table 2. Standard Loading Faktor (SLF)

\begin{tabular}{|c|c|c|c|c|c|c|}
\hline \multirow{2}{*}{ Variables } & TEC & EDU & SKILL & INO & HR & \multirow{2}{*}{ Conclusion } \\
\hline & SLF & SLF & SLF & SLF & SLF & \\
\hline TEC1 & 0.66 & & & & & Good \\
\hline TEC2 & 0.82 & & & & & Good \\
\hline TEC3 & 0.68 & & & & & Good \\
\hline TEC4 & 0.81 & & & & & Good \\
\hline EDU1 & & 0.55 & & & & Good \\
\hline EDU2 & & 0.72 & & & & Good \\
\hline EDU3 & & 0.77 & & & & Good \\
\hline EDU4 & & 0.85 & & & & Good \\
\hline EDU5 & & 0.83 & & & & Good \\
\hline SKILL1 & & & 0.66 & & & Good \\
\hline SKILL2 & & & 0.83 & & & Good \\
\hline SKILL3 & & & 0.88 & & & Good \\
\hline SKILL4 & & & 0.84 & & & Good \\
\hline SKIL5 & & & 0.92 & & & Good \\
\hline INO1 & & & & 0.83 & & Good \\
\hline INO2 & & & & 0.83 & & Good \\
\hline INO3 & & & & 0.67 & & Good \\
\hline HR1 & & & & & 0.67 & Good \\
\hline HR2 & & & & & 0.73 & Good \\
\hline HR3 & & & & & 0,75 & Good \\
\hline HR4 & & & & & 0.77 & Good \\
\hline
\end{tabular}


Evaluation of the validity of the measurement model can be seen in the table which shows the standard loading factor (SLF). From this table it can be said that the construct or measurement model has good validity because the Standard Loading Factor (SLF) is> 0.05 (Igbaria in Setyo, 2008)

The sample size should not be small because SEM relies on tests that are sensitive to sample size and the magnitude of differences in covariance matrices. In theory, the sample size ranges from 200 - 400 for models that have indicators between 10-15. Multicollinearity is assumed to be absent, but the correlation between all independent variables can be modeled explicitly in SEM. Complete multicollinearity will produce single covariance matrices, in which the researcher cannot perform certain calculations such as matrix inversion because division by zero will occur.

Latent variables are unobserved variables or referred to as constructs or other names are factors that are measured using the respective indicators. Latent variables include independent, intermediate and dependent variables. "Exogenous" variables are independent variables with no previous causal variables. "Endogenous" variables are intermediate variables which can be the effect of other exogenous variables or intermediate variables and are causes to other intermediate variables and dependent variables, and can function as actual dependent variables. The variables in a model can either flow upstream (upstream) or downstream depending on whether these variables are considered to be cause or effect. The representation of the latent variables depending on their relationship to the observed indicator variables is one of the characteristics of SEM.

The endogenous construct or dependent variable in this study is the readiness of human resources in Sumatera Utara in facing the free market. Endogenous latent variables or dependent variables in this study are measured by generating indicator variables. The technology exogenous latent variable (TEK) is measured by generating TEC1, TEC2 TEC3 and TEC4; the exogenous educational latent variable (PEND) is measured by generating EDU1, EDU2, EDU3, EDU4 and EDU5; skill latent variable (SKILL) is measured by generating SKILL1, SKILL2, SKILL3, SKIL4 and SKILL5; and the exogenous innovation latent variable (INO) was measured by generating INO1, INO2 and INO3. 
Figure 1. Calculation Results of Lisrel Standardized Solution

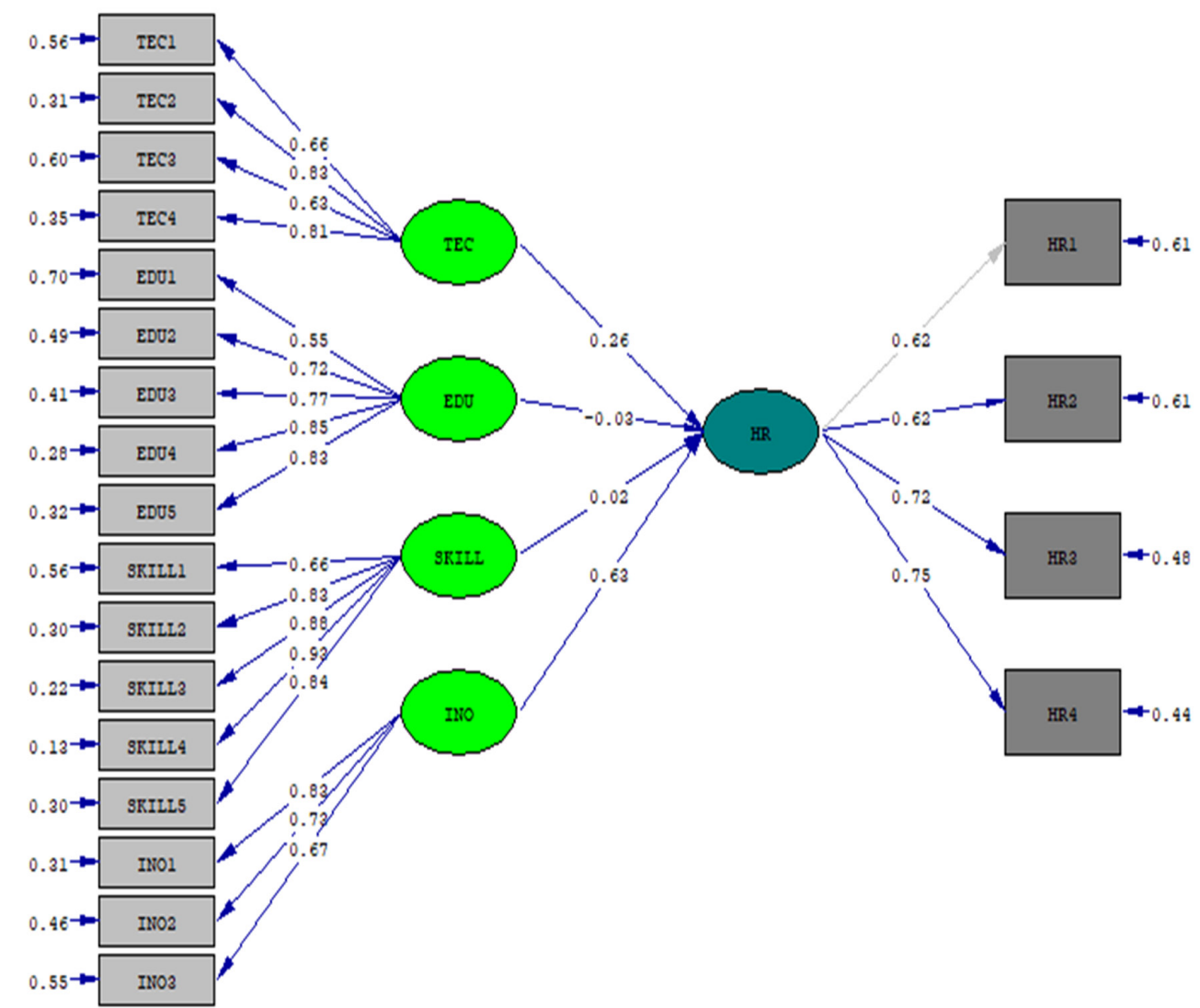

Chi-Square $=197.41, \mathrm{df}=179, \mathrm{P}-\mathrm{value}=0.16438, \mathrm{RMSEA}=0.023$

Fig. 2. Lisrel t-Value Calculation Results

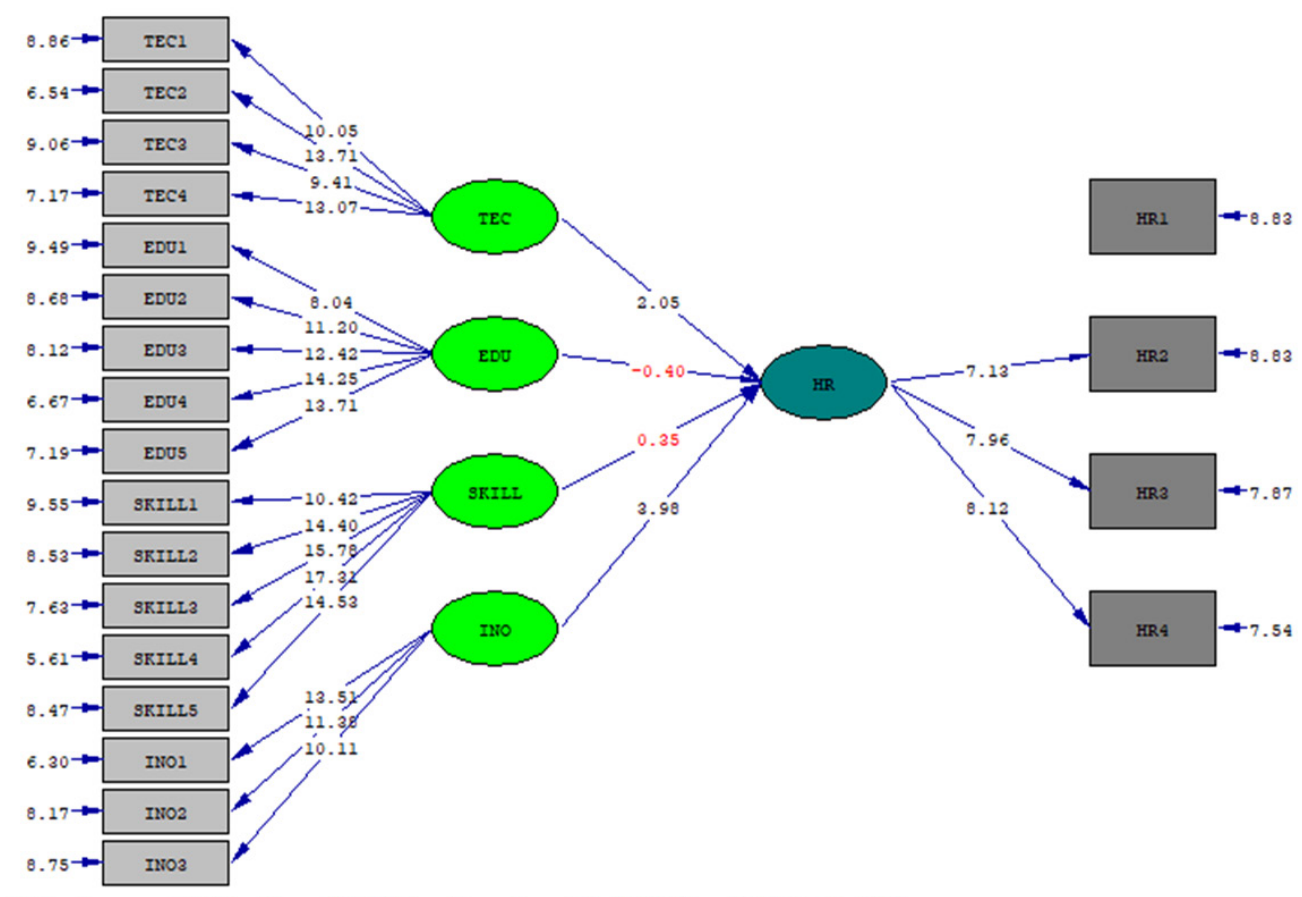

Chi-Square $=197.41, \mathrm{df}=179, \mathrm{P}-\mathrm{value}=0.16438, \mathrm{RMSEA}=0.023$ 
Table 3. Results of the Structural Model Significance Test

\begin{tabular}{|c|c|c|}
\hline Influence Between Latent Variables & t- value & Conclusion of Significance Test Results \\
\hline $\begin{array}{l}\text { H1: The influence of technology on the readiness } \\
\text { of human resources in Sumatera Utara in facing } \\
\text { the free market. }\end{array}$ & 2.05 & $\begin{array}{l}\mathrm{HO} \text { is rejected, the data supports the research } \\
\text { model }\end{array}$ \\
\hline $\begin{array}{l}\text { H2: The influence of education on the readiness } \\
\text { of human resources in Sumatera Utara in facing } \\
\text { the free market. }\end{array}$ & -0.40 & $\begin{array}{l}\mathrm{HO} \text { is accepted, the data do not support the } \\
\text { research model }\end{array}$ \\
\hline $\begin{array}{l}\text { H3 The effect of skills on the readiness of human } \\
\text { resources in Sumatera Utara in facing the free } \\
\text { market. }\end{array}$ & 0.35 & $\begin{array}{l}\mathrm{HO} \text { is accepted, the data do not support the } \\
\text { research model }\end{array}$ \\
\hline $\begin{array}{l}\text { H4 The influence of innovation on the readiness } \\
\text { of human resources in Sumatera Utara in facing } \\
\text { the free market. }\end{array}$ & 3.98 & $\begin{array}{l}\mathrm{HO} \text { is rejected, the data supports the research } \\
\text { model }\end{array}$ \\
\hline
\end{tabular}

After a valid and reliable measurement model of the research model is obtained, the next step is to conduct a structural model analysis of the research model. This analysis is related to testing the research hypotheses. The research hypothesis is accepted if the absolute number $t$ value $>1.96$ with a coefficient sign in accordance with the proposed research hypothesis (positive or negative). The results of the Structural Equation Modeling (SEM) analysis show that the hypothetical model or the theoretical model is able to explain the empirical facts in the field even though there are still variables that have a load factor value $<1.96$, where this model is the most optimal model.

The readiness of human resources in Sumatera Utara in facing the free market is based on four dimensions, namely education, language, skills and innovation. The influence of culture and education has no contribution to the readiness of human resources in Sumatera Utara in facing the free market and is not significant. Meanwhile, education, skills and innovation have contributed to the readiness of human resources in Sumatera Utara in facing the free market.

Tabel 4. Goodness Of Fit Index (GOFI)

\begin{tabular}{cccc}
\hline GOFI & Calculation & Standard Value & Conclusion \\
\hline p-value & 0.16438 & $p$-value $\geq 0.05$ & Good \\
RMSEA & 0.023 & RMSEA $\leq 0.08$ & Good \\
NFI & 0.91 & $\mathrm{NFI} \geq 0.90$ & Good \\
$\mathrm{NNFI}$ & 0.98 & $\mathrm{NNFI} \geq 0.90$ & Good \\
$\mathrm{CFI}$ & 0.98 & $\mathrm{CFI} \geq 0.90$ & Good \\
$\mathrm{IFI}$ & 0.98 & $\mathrm{IFI} \geq 0.90$ & Good \\
$\mathrm{RFI}$ & 0.890 & $\mathrm{RFI} \geq 0.90$ & Good \\
$\mathrm{GFI}$ & 0.91 & $\mathrm{GFI} \geq 0.90$ & Good \\
\hline
\end{tabular}

Goodness of fit tests determine if a model being tested should be accepted or rejected. This total congruence test will not determine the specific pathways in a model to be significant. If a model is accepted, the researcher will then interpret the path coefficients 
in the model. It should be noted that significant path coefficient in misaligned models will be meaningless. In cases where the variables have a low correlation, the structural (lane) coefficients will also be low. The researcher must provide information about not only the alignment measurements, but also all structural coefficients so that the path strengths in the model can be assessed.

The fit model test that can be seen in the table shows that the overall model have good conclusions. This can be seen first of all from the Root Mean Square Error of Approximation (RMSEA) value of 0.023. For the Comparative Fit Index (CFI) the model fit test shows a value of 0.98 which indicates a good level of fit because it is almost close to 1. The value of the Goodness of Fit Index also shows a good value of 0.91 , which indicates that the model is acceptable (acceptable fit).

Knowledge plays an important role in the economy, therefore it must be developed and managed effectively so that companies can improve their performance. To achieve this goal, companies must increase investment in research and development (R\&D), education and training, as well as other intangible investments, all of which must be prioritized and developed beyond tangible assets. The era of the knowledge economy has several important characteristics, including the increasing importance of knowledge as an intangible production factor, the formation of strategic partnerships and partnerships, and the rapid change in strategy in a network, namely a knowledge-based economy.

In today's competitive conditions, there are many organizations that are innovative and appreciate the value of knowledge to improve their products and services. There are several reasons why the concept of knowledge management has begun to be applied. Many organizations have begun to rely on knowledge to create their strategic advantage. With the available knowledge but its scattered or fragmented nature, organizations often spend their time and resources or even fail to achieve the highest quality and experienced knowledge available in the organization. Organizations that employ knowledge management have found that through knowledge networks, organizations can create new products and services that are better and faster.

Intellectual assets are a key success factor in competing in responding to changes in the business environment and rapid technological advances that have an impact on the emergence of a knowledge-based society and economy. The knowledge-based economy shows a trend that the economy is more dependent on high levels of knowledge, information and skills, and ensures the availability of these intangible assets. In this condition, the role of competent human resources is needed to ensure the survival of the company, namely human resources based on knowledge and skills so that they can master the development of existing technology. Knowledge-based human resource development requires a learning process that supports both self-learning and organizational learning (Setiarso, 2003).

Sumatera Utara is currently very intensively attracting many investors to invest in Sumatera Utara. If this becomes a reality, the economy will grow rapidly and the demand for labor will be quite high. This will also trigger a heavy influx of labor to Sumatera Utara, which due to globalization reasons, this flow will not be prevented, except by increasing the bargaining power of local workers against foreign workers. 
The Sumatera Utara Provincial Government must make efforts as early as possible to prepare reliable and highly competent human resources. To be able to win the competition with foreign workers, both when they enter Sumatera Utara or when Sumatera Utara workers are looking for opportunities in the global market, individual competence as a professional must be demonstrated. A professional must have a vision and mission that is far-reaching, broad-minded, responsive to developing issues, and able to communicate well.

One of the main obstacles for Sumatera Utarans to get better job opportunities or access to education abroad is the factor of mastery of foreign languages skills and the communication skills. This is important because the knowledge and abilities possessed will be of no use if it is not accompanied by the ability to convey it to others. The world in Sumatera Utara will sooner or later be dragged or even consciously into the world, especially when free trade is actually implemented. As a result, the competition in the labor market will get tighter along with the ever increasing demands. Investments in human resource development do require large financial support and a lot of time. The current efforts will not produce results in the near future.

Therefore, the Provincial Government of Sumatera Utara continues to improve its human resource planning strategy, which has actually started by laying a strong foundation at the level of education, both physically and psychologically. But it needs a strong relationship between education and industry so that education can become one of the strong industrial motors. In addition, the preparation of human resources must be supported by an education system that can accommodate the needs of the market to provide an independent and skilled workforce, while still paying attention to the virtues of religious education and noble morals (ethics).

Academics, business, society, legislators, and the government must support the strengthening of Human Resources (HR) and Science and Technology (IPTEK) in an effort to improve the quality of human resources as an effort to compete in the free market. One of the keys to the successful implementation of HR readiness is smart planning and utilization of human resources potential in the context of developing Sumatera Utara Province. Steps that can be taken in an effort to strengthen human resource capabilities can be done by optimizing education to improve various competencies. In addition, increasing the number of graduate people in science and technology is becoming more important. The readiness of human resources in the free market cannot be denied that the future challenges that must be faced by Indonesia are global market integration. In addition, from the human resources side, it still shows the low competence of human resources and management in certain fields due to the lack of various factors. Based on the results of this study, HR readiness is influenced by four dimensions, namely readiness to use technology and the ability to innovate.

Mastery of technology is very important for the readiness of human resources in Sumatera Utara Province because many industries in Sumatera Utara Province use capital or are capital intensive by using sophisticated equipment and using the latest technology, both machines and administration already using high technology. Many of these technologies are imported from abroad, especially machine tools that are run with an integrated information system. To run this machine requires skill and ability to use these various tools. From the respondents 'answers, the most respondents got the answers that were quite good 
at mastering technology, where of course the respondents' answers were expected to be good. The managers see that in this Province there are still many shortages of experts in the field of information technology and other technology and for this deficiency they are brought in from outside the Province of Sumatera Utara and this is related to the education in this area. Managers are still not sure that university graduates are able to compete with graduates from outside, especially from developed countries such as Australia, Singapore and others. Industrial companies in Sumatera Utara also employ local workers who graduated from abroad, where universities located in Sumatera Utara are still considered unable to compete at the international level widely. In addition, even if there are graduates from a good local universities, the number is very limited and difficult to obtain because many jobs that require their expertise, especially are still imported from outside Sumatera Utara such as from Java. If the company is headquartered in Java, a lot of human resources will be brought in from Java.

The ability to innovate according to managers in Sumatera Utara is quite low and there is not much product development and work systems in Sumatera Utara Province. Weak ability to create and innovate can be seen in the ability in the field of research and development. Not one of the respondents or managers has ever used the results of research at research institutes in Sumatera Utara, whether from higher education institutions or other research institutions. It can be seen that the influence of innovation has a significant effect on the readiness of human resources in Sumatera Utara.

Skills have an effect on the readiness of human resources, where according to managers that workers in Sumatera Utara Province still need to improve their skills at work. For example, in the construction of various high-rise buildings in Medan, it is very dependent on labor from the island of Java, especially Jakarta, this is because they are used to building multi-storey buildings. This ability is rarely possessed by construction workers in Medan because to speed up development workers are brought in from Java. Likewise in industry, many skilled workers are brought in from Java as operators of industrial machinery.

Thus, the readiness of human resources in Sumatera Utara Province still needs to be addressed, especially regarding expertise in technology, innovation and other skills. Lack of readiness of human resources in this field, of course, could hinder competition in the economy in general and in human resources in particular.

\section{REFERENCES}

Tîțu, M. A., Stanciu, A., \& Țîțu, S. (2018). Business Process Outsourcing. Integrity in an era of digital transformation. Journal of Electrical Engineering, Electronics, Control and Computer Science, 4 (1), pp 1-4.

Fenech, R., Baguant, P., \& Ivanov, D. (2019). The changing role of human resource management in an era of digital transformation. Journal of Management Information and Decision Sciences , 22 (2), pp 1-10.

Guler, I., Guillén, M. F., \& Macpher, J. M. (2002). Global Competition, Institutions, and the Diffusion of Organizational Practices: The International Spread of ISO 9000 Quality Certificates. Administrative Science Quarterly, 47 (2) pp. 207-232. 
Higgins, J. (2014). Bringing HR and finance together with analytics. HR magazine, 59 (11), pp. 11-13.

Kamukama, N. (2013). Intellectual capital: company's invisible source of competitive advantage. International Business Journal, 23 (3), pp. 89-78.

Mankiw, N. G. (2006). The Macroeconomist as Scientist and Engineer. Journal of Economic Perspective, 20 (4), pp. 29-46.

Salim, J. S., Harta, F. C., Shania, I., \& Devie, D. (2019). Does Intellectual Capital Affect the Competitiveness of Public Accounting Firms in Indonesia? 1st Annual Management, Business and Economic Conference (AMBEC 2019) Batu, East Java: Atlanttic Press.

Türkmen , E. (2020). The Effects of Digital Transformation on Organizations. Istanbul, Turkey: IGI Global.

United Nations Development Programme (UNDP). (2019). Human Development Report 2019, Inequalities in Human Development in the 21st Century Briefing note for countries on the 2019 Human Development Report. New York: United Nations Development Programme.

Ustundag, A., \& Cevikcan, E. (2018). Industry 4.0: Managing The Digital Transformation. Istanbul: Springer Series in Advanced Manufacturing.

(https://ipm.bps.go.id/ data/provinsi/metode/baru/1200, accessed on May 11, 2020) 